\title{
Strategic Censorship in a Hybrid Authoritarian Regime? Differential Bias in Malaysia's Online and Print Media
}

\author{
Jason Abbott and John Wagner Givens
}

\begin{abstract}
We analyze and compare three separate efforts to code bias in Malaysia's media and find strong empirical evidence of an ongoing and profound progovernment bias in coverage. We also find, however, significant variation in bias between different types of news outlets. While Malay and Anglophone sources tended to be strongly progovernment, Chinese-language and online outlets were far more impartial. We demonstrate that both the general bias and the variation in it are largely the result of two factors: (1) government censorship and (2) ownership structures that link many major outlets to the ruling coalition. These findings provide a detailed view of the struggle for media independence in a less-than-democratic regime and supply insight into media bias across both authoritarian and democratic regimes in Asia, as well as outside it. Keywords: censorship, new media, elections, Malaysia, electoral authoritarianism, newspapers, political bias
\end{abstract}

Since Malaysia gained its independenCe in 1957, the Barisan Nasional (BN) coalition, of which the largest constituent party is the United Malays National Organization (UMNO), has won decisive victories in every one of the country's thirteen general elections. ${ }^{1}$ A major reason for their success is the extensive influence they have exercised over Malaysia's media, which has led to a strong media bias in favor of the $\mathrm{BN}$ and against opposition parties. Indeed, in recent international rankings of press freedom, Malaysia has consistently placed among the worst-performing countries, falling from 96th place in 2006 to 132nd in 2008 and 147th in 2014, its worst ever ranking. ${ }^{2}$

The BN's control of the Malaysian press is extensive and operates through two primary mechanisms. First, legislation restricting freedom of speech allows the government to censor articles, harass journalists, and even shut down uncooperative media outlets. Second, ownership structures link many of the major outlets to the $\mathrm{BN}$ and its cronies 
(Rodan 2004). As a result, the media in Malaysia is at best "shackled" (Brown 2005) and at worst subject to stringent controls (Sani 2005).

Yet it has been widely recognized that there is significant variation between different types of outlets. In particular, the Chinese and Anglophone presses have traditionally been viewed as less biased than the Malay-language media (George 2007). Additionally, over the past fifteen years, vibrant online news portals have emerged to give a greater voice to dissident and opposition viewpoints (Abbott 2001, 2011; Abbott, MacDonald, and Givens 2013; George 2007; Gong 2011; Liow 2012; Surin 2010; Tapsell 2013; Weiss 2013).

This shifting mediascape suggests a broader theme visible in both harder authoritarian regimes like China and semi-authoritarian regimes such as Russia and Singapore: that control of the media is an important political battleground, with government seeking to impose greater controls and more independent media outlets seeking to evade them.

In this research note we review a variety of projects, including our own ongoing effort, to code bias in Malaysian print and online media and provide a clearer view of political influence on these media; these projects are of wider interest to an understanding of media bias across both authoritarian and democratic regimes in Asia, as well as outside it. We find substantial variation in the extent of bias across outlets, which can be at least partially explained by variations in ownership, as well as legislation and the enforcement of government censorship.

\section{Overview of Print Media}

According to Nielsen, the overall daily readership of newspapers in Malaysia stands at approximately 9.1 million, equivalent to just under half of the population aged over fifteen years (Thean 2013). Malay-language papers account for approximately 55 percent circulation, while Chinese and Anglophone papers each make up about 22 percent (Malaysia Audit Bureau Circulations Various Years). The majority of readership is dominated by a handful of papers, which are consolidated in the hands of a small number of tycoons and holding companies.

The New Straits Times Press (Malaysia) Bhd (NSTP) owns both the Anglophone New Straits Times, Malaysia's oldest still-printed newspaper, and Berita Harian (Daily News), which was the leading Malaylanguage newspaper until 2005. In 1991, the NSTP added to its dominance by launching the Harian Metro, a compact (tabloid) targeted at a young urban audience, which became Malaysia's best-selling newspaper by 2005 . Although the NSTP is not directly state owned, it is 
linked to UMNO by close personal connections and share ownership in various holding companies, especially the publicly traded Media Prima, one of Malaysia's largest media conglomerates (Chin 2015 ). As a result, the NSTP's papers are considered to be at best progovernment and at worst semiofficial mouthpieces for the ruling coalition.

Utusan Malaysia (the Malaysia Courier) was founded in 1939 as a vehicle for Malays to express their opinion on British colonial rule. Before its readership began to decline in 2004, it was one of the country's leading Malay-language newspapers by circulation and readership. With UMNO directly owning a controlling stake in the paper, it has attracted widespread criticism from the country's opposition parties and liberal intelligentsia for allegedly stoking racism in a country in which racial identity remains the principal societal cleavage (Abbott 2011).

Currently, the best-selling Chinese-language daily newspaper in Malaysia is Sin Chew Daily (formerly Sin Chew Jit Poh). In 1987, Sin Chew suffered significant financial woes following its temporary suspension during a political crackdown known as Operation Lalang. This led to the takeover of the company by Sarawak timber tycoon Tiong Hiew King, who four years later acquired Guan Ming Daily, Malaysia's third-ranked Chinese paper (Eng 2003). Nanyang Siang Pau had been the best-selling Chinese paper in Malaysia until the 1980s when it was overtaken by Sin Chew Jit Poh. In 1993, its parent company, Nanyang Press, also took over China Press, currently the country's second-most popular Chinese paper. Nanyang suffered a severe downturn in its circulation in 2001 following protests from readers and advertisers about the takeover of the newspaper by the investment arm of the Malaysian Chinese Association (MCA), the BN's primary Chinese party. Unable to recover its earlier market share following the controversy, Nanyang was subsequently reoriented as a niche business newspaper. In 2008, Tiong's Sin Chew Media Corp merged with Nanyang Press to create Media Chinese International (MCI) and two years later the MCA sold its stake in the company (Ting 2010). Thus, today a single media conglomerate controls three of the main Chinese newspapers, which between them command more than 70 percent of Chinese readership (Malaysia Audit Bureau Circulations Various Years).

The only major Chinese-language challengers to MCI's dominance come in the form of papers owned by Lau Hui Kiang, a competitor of Tiong's. Kiang owned East Malaysia's most popular Chinese paper, See Hua Daily, and supported the founding of the Oriental Daily by journalists who left Nanyang after its acquisition by the MCA (Sun 2009).

Despite having divested from its Chinese-language holdings, the 
MCA still exerts significant influence on Malaysia's media through its ownership of The Star, which dominates the Anglophone market with a circulation over twice that of its main rival the New Straits Times (Malaysia Audit Bureau Circulations Various Years). First published as a regional newspaper in Penang in 1971, The Star became a national weekday tabloid from 1976 onward. A commercial success, its online version vies with the online-only Malaysiakini for the title of most visited news portal.

In sum, the largest papers in Malaysia, accounting for the majority of circulation, are in the hands of a few major holding companies, individuals, and parties. Yet, a linguistic divide is evident. Most major Malay and Anglophone papers are linked to the BN, while the ownership of Chinese-language newspapers is largely split between two tycoons. As will be seen, these ownership differences have material effects.

\section{Online Media}

A survey of the top news websites in Malaysia reveals a very different picture from that of the print media. While all of the major newspapers have an online version, only four make it into the top fifty Malaysian websites, where they are joined by Malaysiakini and the Malaysian Insider. Although it is difficult to compare the readership of websites with that of newspapers, both Malaysiakini and the Malaysian Insider have sizable readerships that have made them insurgent players in the overall Malaysian mediascape. Malaysiakini records on average 9 million page views a month $\left(300,000\right.$ per day) and 664,000 unique visits $^{3}$ a month. ${ }^{4}$ The Malaysian Insider has rapidly developed a substantial readership exceeding 500,000 unique visitors a month.

Founded by former Star journalist Steven Gan and businessman Prem Chandran in November 1999, Malaysiakini is the country's oldest news portal. While the site proved immediately popular, it was plagued with political controversy over funding from George Soros and the US-based National Endowment for Democracy. The site has also been subject to repeated denial of service attacks since its inception, and its journalists have frequently been denied official press passes. Despite such challenges, Malaysiakini was one of the first online news portals in the world to adopt a subscription paywall to provide the company with a consistent revenue stream, which has been supplemented by robust growth in private advertising following a surge in traffic to the site during the 2008 election campaign. By 2011-2012, advertising revenue 
surpassed subscriptions as the largest source of income for the news portal and even the BN began advertising with them. As Gan explains, "Najib [the prime minister] realized that urban voters were not reading newspapers like The Star and so the BN was no longer reaching them." 5 During the election of 2013, traffic to Malaysiakini again surged, peaking at 4.3 million page views on election night alone. ${ }^{6}$

The Malaysian Insider was created in February 2008 by a group of businessmen and journalists who were joined in 2010 by Jahabar Sadiq, a former Reuters television producer, as CEO and editor. While the news portal generates revenue from advertising, the bulk of its funding comes from anonymous businessmen who, according to Jahabar, "liked the idea of an impartial website."7 For these investors, Malaysiakini was seen as essentially being pro-opposition by default: "Malaysiakini was pushed into a corner ... a reaction to the mainstream press. They hated the fact the press was so pro-government and wanted to balance the news. As a result they became too pro-opposition with not enough critique and analysis." 8

Free Malaysia Today (FMT) is both the newest and smallest onlineonly news portal. Prior to $2010, F M T$ had been a blog affiliated with the Pakatan Rakyat opposition coalition, but reoriented itself as a news portal when K. Kabilan took over the site. FMT has recently sought to carve a niche out for itself by launching a dedicated news portal catering to Sabah and Sarawak, the states of East Malaysia. ${ }^{9}$

The limitations of online media notwithstanding, the contrast with Malaysia's traditional media is striking. As opposed to strong printmedia links to the $\mathrm{BN}$, major online outlets tend to be owned by independent or even opposition-linked figures. This relative independence may help explain the success of online news portals in increasingly winning larger audiences and major advertisers.

\section{Coding Bias and Data Analysis}

In this article we examine three separate efforts at coding political bias in Malaysia's media. First, we look at the most comprehensive study to date of media coverage in Malaysia, "Watching the Watchdog," a 2013 project conducted by the University of Nottingham Malaysia Campus and the Center for Independent Journalism. Second, we address content analysis of three major Malaysian websites conducted by Linda Lumsden, a professor of journalism at the University of Arizona. Third, we explore our own ongoing efforts, started in 2010, to code several major Malaysian print outlets. While each of these coding projects has its own 
advantages and drawbacks, using data from three separate studies, which rely on different units of analysis and techniques of data collection, allows us to provide a wider overview of Malaysia's media. Perception of bias in media sources is inherently subjective, but broad agreement among these three studies suggests that the patterns of bias we find in Malaysia's media can be measured empirically and are profound.

\section{Study One: Watching the Watchdog}

In 2013, Watching the Watchdog (WtW) employed a team of approximately seventy coders who analyzed twenty-seven news outlets, consisting of seventeen newspapers, six television stations, four news websites, and two news agencies. Our study makes use of all of these sources except the TV stations, as we focus exclusively on written media. The sources were monitored in the run-up to Malaysia's 2013 general election, from April 7 to May 7. From the twenty-seven outlets, the $\mathrm{WtW}$ team selected for coding front-page stories, editorials, articles in the Malaysian news sections of news websites, or other articles that were more than one-third about the election. Coders identified the tone (positive, negative, neutral, or attacked) of individual sentences based on the emotive, descriptive, and subjective language and vocabulary used. The project employed sentence-level content as the unit of analysis in order to generate extremely conservative estimates of bias. ${ }^{10}$ Perhaps surprisingly, this did not result in large differences in measures of bias produced by $\mathrm{WtW}$ and the other studies examined here, which used article-level bias.

To date, WtW has not run any extensive statistical analysis and has released its data only in a fairly aggregated form through five mediumterm and two comprehensive final reports, as well as twenty-eight individual media publication reports. The most disaggregated data made available by $\mathrm{WtW}$ are tables published in the individual media reports, which provide statistics on how often forty-five prominent Malaysian political figures were mentioned and whether the tone was positive, negative, neutral, or attacked. These include eighteen BN figures, twentythree Pakatan Rakyat (PR) figures, and four independents. By collecting the data on these forty-five figures across each of the twenty-seven outlets, we have constructed a dataset of 1,215 cases, which we use to test biases across media outlets by language and type. For each figure we construct a simple measure of net bias. This was done by adding the total number of positive and neutral mentions minus the total number of mentions in which the figure was portrayed negatively or attacked. 
Table 1 shows that WtW finds a strong and statistically significant bias in favor of BN political figures and against PR and independent figures in both the Bahasa Malay and Anglophone media. The measure we constructed for the $\mathrm{WtW}$ data subtracts total negative from positive mentions for each figure, producing increasingly large positive numbers the more often a figure is covered in a positive light. Using this measure, $\mathrm{BN}$ figures in the Malay-language media received an average net number of approximately four mentions, while PR and independent figures ranked an average net of 2.68 negative mentions.

In terms of the Anglophone press, WtW's data (Table 1) demonstrate large and statistically significant biases in favor of $\mathrm{BN}$ figures and against PR and independent figures in the five Anglophone newspapers, two websites, and one wire service they examined. Indeed, WtW's data show a pro-BN bias in the Anglophone media that is almost identical to the level of bias it found in the Malay media. The BN netted an average of 4.1 positive mentions to the PR and independent net average of 2.7 negative mentions.

WtW's analysis of five Chinese-language newspapers shows a dramatic difference between it and the Malay and Anglophone press. Table 1 confirms the established wisdom that Chinese outlets did not provide significantly more positive coverage for the BN.

\section{Table 1 Bias in Coverage Found by Watching the Watchdog} (2-tailed T-tests)

\begin{tabular}{|c|c|c|c|}
\hline$N$ & Mean & $\begin{array}{l}\text { Standard } \\
\text { Error }\end{array}$ & $\begin{array}{l}\text { Standard } \\
\text { Deviation }\end{array}$ \\
\hline \multicolumn{4}{|c|}{ Net Bias in Coverage of Political Figures by Bahasa Malay } \\
\hline $\mathrm{BN}$ figures 144 & 4.02 & 1.51 & 18.10 \\
\hline$P R$ and independent figures & -2.68 & 0.73 & 10.71 \\
\hline Difference: & -6.70 & P-value: & 0.00 \\
\hline \multicolumn{4}{|c|}{ Net Bias in Coverage of Political Figures by Chinese Outlets } \\
\hline BN figures $\quad 90$ & 0.86 & 1.29 & 12.25 \\
\hline$P R$ and independent figures 135 & -0.57 & 0.63 & 7.37 \\
\hline Difference: & -1.43 & P-value: & 0.14 \\
\hline \multicolumn{4}{|c|}{ Net Bias in Coverage of Political Figures by Anglophone Outlets } \\
\hline $\mathrm{BN}$ figures 144 & 4.10 & 1.49 & 17.90 \\
\hline $\mathrm{PR}$ and independent figures & -2.74 & 0.61 & 8.94 \\
\hline Difference: & -6.84 & P-value: & 0.00 \\
\hline \multicolumn{4}{|c|}{ Net Bias in Coverage of Political Figures by Online Outlets } \\
\hline $\mathrm{BN}$ figures $\quad 72$ & -0.06 & 0.59 & 4.98 \\
\hline $\mathrm{PR}$ and independent figures 108 & 0.04 & 0.51 & 5.26 \\
\hline Difference: & 0.10 & P-value: & 0.45 \\
\hline
\end{tabular}


WtW's data also support the impartiality of online news. WtW coded articles from two of the same websites as our second study, Malaysiakini and Malaysia Insider, but coded both the Anglophone and Malay-language versions of each site. This could be crucial given what we have learned about the significant differences in media bias across Malaysia's linguistic divides. Table 1 shows that average net mentions of both BN and opposition/independent figures were almost zero. This means not only that online outlets treated both parties equally but that both were praised almost exactly as often as they were criticized.

\section{Study Two: Lumsden}

Our second source of data comes from content analysis conducted by Linda Lumsden, a professor of journalism at the University of Arizona. Lumsden selected for analysis Malaysia's three most popular onlineonly news websites: Malaysiakini, the Malaysian Insider, and Free Malaysia Today. Lumsden identified the top ten news stories for each of the sites every day for fifteen days, from April 21, 2013, through Election Day. She examined the headlines and text and coded the 450 articles according to theme and vocabulary. Articles were classified as positive $\mathrm{BN}$, negative $\mathrm{BN}$, positive opposition, or negative opposition, as well as additional categories not relating directly to either party. Unlike the other studies addressed here, a single person conducted all the coding in Lumsden's study. While this decreases the chance of an apparent bias emerging merely from a difference in opinion between coders, it increases the influence of a single perspective, especially given the coder is also the primary researcher.

As was the case for WtW, Lumsden's raw data were not made available to us. She does, however, provide fairly disaggregated data in the form of tables that list how many of each category of article (positive/negative and BN/opposition) were present daily on each news site during the period. We collected these data and then constructed a simple measure of net bias by subtracting the total number of positive articles by the total number of negative articles for each website each day. This yields forty-five cases that we use to test for bias.

Our analysis of Lumsden's data (Table 2) makes it clear that Malaysia's top three online news portals presented largely balanced reporting. When we create a net number of pro-BN/pro-opposition articles per day, ${ }^{11}$ we find a less-than-one article per day difference, which is far from statistically significant. While not visible in the aggregate data presented in Table 2, Malaysiakini and Free Malaysia Today were more critical in their coverage of the government than the Malaysian Insider. 
Table 2 Top Three News Sites Bias in Online Coverage Found by Lumsden (2-tailed T-tests)

\begin{tabular}{lcccc}
\hline & $N$ & Mean & $\begin{array}{c}\text { Standard } \\
\text { Error }\end{array}$ & $\begin{array}{c}\text { Standard } \\
\text { Deviation }\end{array}$ \\
\hline BN bias & 45 & 0.16 & 0.38 & 2.52 \\
PR bias & 45 & 0.96 & 0.33 & 2.24 \\
& Difference: & -0.80 & P-value: & 0.47 \\
\hline
\end{tabular}

Yet, none of the papers could be accused of being strongly biased in favor of the opposition. By demonstrating a willingness to be critical of the opposition, as well as the government, the online news media in Malaysia is demonstrating that "they are not just mouthpieces for the opposition ... [but] play the role of journalistic watchdog" (Lumsden 2013, 20).

\section{Study Three: Abbott and Givens}

In 2010, Jason Abbott began a process of coding Malaysian newspapers in order to measure whether they exhibited progovernment or pro-opposition bias. The project began with two Malay-language newspapers, Utusan Malaysia and Berita Harian (Abbott 2011). Both were coded for the month preceding the federal election of March 8, 2008, as well as the same period two years earlier as a control. Since then, further coding was conducted to include the 2013 election. To date, coding has been completed for Utusan Malaysia (2006, 2008, and 2013), Berita Harian (2006 and 2008), the New Straits Times (2008 and 2013), and Sin Chew Jit Poh (2013).

The coding of the data by Abbott followed a detailed codebook and coding instructions modeled on one created by the Comparative $\mathrm{Na}$ tional Elections Project ${ }^{12}$ for the 1992 US presidential election. For all the newspapers coded in 2008 and 2013, the time period selected was approximately a month preceding national elections. For 2008 , this period ran from February 11 to March 8; in 2013, from April 17 to May 5.

The coding of Malay-language newspapers was conducted by two native Malay speakers, one Singaporean and one Malaysian, while the coding for Sin Chew Jit Poh was conducted by a Malaysian-Chinese researcher studying at the Australian National University. The New Straits Times was coded by Abbott with the assistance of a graduate student. To address questions about objectivity, the decision was taken not to employ researchers solely from Malaysia in order to avoid pre- 
conceptions the coders may have had that could have colored their assessment of the bias in the newspapers under investigation.

Coders were instructed to code any and all stories that were primarily about government and/or politics from the target newspaper or website during the selected period. They were instructed not to include sports, lifestyle, or finance (unless a financial story was explicitly political). As a result, the numbers of items coded vary between publication and time period based on the number of articles in the publication and the percentage of articles with political content.

Five variables were explicitly coded for degrees of bias/partisanship: government bias, opposition bias, reporter tone, evaluation of actor in article, and evaluation of actor in photo. The coders were instructed to code for the article as a whole and from the perspective of the Barisan Nasional and opposition separately. We make direct use only of the government bias and opposition bias variables, which were coded on a seven-point Likert scale ( 1 being extremely critical to 7 being extremely positive). Since the Likert scale uses separate numbers for positive or negative bias, there was no need to create a net measure of bias as we did for the previous studies. In comparison with the previous studies analyzed here, the Likert scale allows for greater nuance in the coding of bias, so that fawning praise (7) looks very different from mild approval (5). The downside of such a scale, however, is the inherent subjectivity of differentiating relatively fine degrees of bias, especially between coders. The fact that our own findings so closely match those of the other studies suggests that our results are not simply the product of coding specifications.

Our findings (see Table 3) demonstrate that Utusan Malaysia was predictably biased toward the government and virulently anti-opposition. Looking back to the 2008 data, which analyzed both Utusan Malaysia and Berita Harian, we see that this bias is consistent with their coverage of the last election. On a 7-point Likert scale, the data from 2008 show a difference of 3.27 between the opposition and the $\mathrm{BN}$, while 2013 ranked a 3.59. In his 2011 paper, Abbott found that in the nonelection period from 2006 the opposition is rarely mentioned at all. This contrasts dramatically from the pre-election periods in 2008 and 2013, when the opposition received frequent negative mentions. Indeed, our coding of Utusan in 2013 actually demonstrated that the opposition was mentioned more than the $\mathrm{BN}$.

As we turn our attention to Sin Chew Jit Poh, the most popular Chinese-language daily, Table 3 shows that its coverage of the election campaign was remarkably evenhanded. Both the governing coalition and the 
Table 3 Bias in Online Coverage Found by Abbott and Givens (2-tailed T-tests)

\begin{tabular}{lcccc}
\hline & $N$ & Mean & $\begin{array}{c}\text { Standard } \\
\text { Error }\end{array}$ & $\begin{array}{c}\text { Standard } \\
\text { Deviation }\end{array}$ \\
\hline Utusan Malaysia and Berita Harian, 2008 & 534 & 5.62 & 0.05 & 1.14 \\
BN bias & 459 & 2.35 & 0.05 & 1.16 \\
PR bias & Difference: & -3.27 & P-value: & 0.00 \\
& & & & \\
Utusan Malaysia, 2013 & & & & \\
BN bias & 172 & 5.67 & 0.06 & 0.76 \\
PR bias & 258 & 2.07 & 0.03 & 0.56 \\
& Difference: & -3.60 & P-value: & 0.00 \\
Sin Chew Jit Poh, 2013 & & & & \\
BN bias & 45 & 4.20 & 0.27 & 1.83 \\
PR bias & 39 & 4.08 & 0.28 & 1.72 \\
& Difference: & -0.12 & P-value: & 0.38 \\
New Straits Times, 2008 & & & & \\
BN bias & & & & 0.03 \\
PR bias & 669 & 4.92 & 0.03 & 0.92 \\
& 388 & 3.49 & 0.05 & 0.00 \\
New Straits Times, 2013 & & -1.42 & P-value: & \\
BN bias & & & & 0.94 \\
PR bias & 189 & 5.98 & 0.07 & 1.06 \\
& 133 & 2.05 & 0.09 & 0.00 \\
\hline
\end{tabular}

opposition received coverage that was balanced (neither negative nor positive) with only a very slight and statistically insignificant advantage for the Barisan Nasional in terms of positive coverage. With a mean of 4.20, bias toward the government is only slightly higher than a midpoint on the 7-point Likert scale. Perhaps more interestingly, the opposition is also treated favorably with a mean of 4.08 , making this the only newspaper we coded where coverage of the opposition was generally positive.

In our analysis of 2008 coverage we found that the New Straits Times did betray a progovernment bias (Table 3), but one that was much smaller than those of Utusan Malaysia and Berita Harian for the same period. This makes sense as the New Straits Times has traditionally projected itself as a more somber and professional publication than these Malay tabloids. Looking at their coverage during the 2013 election, however, we see that the paper has become far less neutral since 2008, proving slightly more biased than even Utusan Malaysia. Some familiar with Malaysia's media believe that the paper's increasingly progovernment tone has begun to seriously alienate the educated middle-class 
readership of the newspaper. ${ }^{13}$ This may explain why the paper has seen its circulation fall precipitously from approximately 180,000 prior to the "Reformasi" protests in 1998 to fewer than 75,000 by mid-2014 (Malaysia Audit Bureau Circulations Various Years).

\section{Understanding the Mechanisms of Repression: Directions for Future Research}

The results of the previous section strongly suggest two major features of Malaysia's mediascape: (1) there is a statistically significant progovernment bias in the Malay-language and Anglophone media, and (2) online and Chinese media outlets are much more balanced and neutral in their reportage. In the next section we examine two factors that are commonly believed to be responsible for the strong bias in Malaysia's media-a legislative framework for censorship and a structure of media ownership that closely ties outlets to the ruling coalition.

\section{The Legislative Framework}

As Abbott (2011), Brown (2005), and others have noted, one of the principal factors in explaining the progovernment bias of Malaysia's print media is the multiple legislative checks that allow the state to restrict freedom of speech promised by Malaysia's constitution.

The Official Secrets Act (OSA), passed in 1972, gives the government the power to prosecute any journalist who publishes official information without authorization. In addition to its use against political figures,${ }^{14}$ the OSA has been used against several journalists, including James Clad and Sabry Sharif in $1985^{15}$ and two journalists at the Harian Metro in 1995. ${ }^{16}$

Originally passed by the British to contain anticolonial unrest during the Communist insurgency, the Sedition Act (1948) prohibits "prompting disaffection" with the administration of justice in Malaysia and the public questioning of "sensitive" constitutional issues. ${ }^{17}$ Additionally the act makes it a crime to publish or be in possession of any publication that could be deemed seditious. The Sedition Act has been wielded frequently against government opponents, ${ }^{18}$ bloggers, ${ }^{19}$ and even cartoonists. ${ }^{20}$

The most explicit legislative control of press freedom is the 1984 Printing Presses and Publications Act (PPPA). The act allows the home minister to revoke publishing and permit licenses and provides for a jail term or heavy fine for any editors, journalists, publishers, or individuals who "maliciously" print false information. The PPPA has been used 
on numerous occasions to ban or restrict press freedom. In 1987, four newspapers had their licenses revoked, including Sin Chew Jit Poh and The Star. During the "Reformasi" protests of 1998-1999 the act was wielded against a variety of outlets including the magazines Detik, Tamadun, and Wasilah. It was also used against Harakah, the newspaper of the Islamic party PAS, in March $2001 ; ;^{21}$ the Tamil newspaper Makkal Osai in 2007;22 and the satirical artist Zunar ${ }^{23}$ in 2010.

As is the case with many similar regimes, actual cases of censorship are just the tip of the iceberg. In Malaysia, as in many countries, the threat of censorship or even jail leads to extensive self-censorship by journalists, editors, and owners (Hassid and Stern 2012).

To some extent, the greater neutrality of online media can be explained by the fact that some laws restricting press freedom did or do not apply to online sources, for example the PPPA, and that those that do have been less rigorously applied online. This is not the result of a greater commitment to online press freedom but rather the unintended consequence of a policy of promoting the information technology sector as an engine of development (Abbott 2001; Lepawsky 2005). This relative freedom, especially in contrast to the constraints placed on Malaysia's traditional media, has been partially responsible for rapid growth in the readership of online news (Abbott, MacDonald, and Givens 2013). Prem Chandran, the CEO of Malaysiakini, when asked to comment on the respective roles of print and online media, remarked, "more people get their political news online than in newspapers today. Online media is now the mainstream." 24 Jahabar Sadiq, CEO of the Malaysian Insider, was scathing in his opinion of his print media counterparts, stating that "the editors report directly to the Prime Minister ... they reflect the siege mentality of this government, they need good news, they need to believe the hype, they won't change!"25 Leslie Lau, executive editor of the Malay Mail Online, argued that the effect of media bias was to create "a credibility gap and trust gap between the government and the urban middle classes, that's where online media comes in. ... Online media is leading the charge."26

While the policy allowed online services to build this firm foundation, part of the ruling coalition's initial laxity may have been the result of a lack of understanding of the possible impact of online media. In the words of former prime minister Dr. Mahathir Mohamad, "when I said there should be no censorship of the Internet, I really did not realize the power of the Internet, the power to undermine moral values, the power to create problems and agitate people." ${ }^{27}$ As the Internet has emerged as a powerful voice in Malaysian politics, there has been increasing evi- 
dence of the government's intent and willingness to censor online sources. In 2001, Hishamuddin Rais, a social activist and columnist for the online news service Malaysiakini, was detained under the Internal Security Act for two years. ${ }^{28}$ In 2006 , there was an attempt to force all news-based blogs to register with the Ministry of Information. ${ }^{29}$ In 2008, the prominent civil rights activist and blogger Raja Petra Kamaruddin was detained for two months. ${ }^{30}$ On March 31, 2015, three editors and two executives from the Malaysian Insider were arrested in connection with an article about a proposal for the strict enforcement of Islamic law. ${ }^{31} \mathrm{~A}$ few weeks later, Malaysia's parliament approved amendments to the sedition law that grant broad new powers to censor online media. ${ }^{32}$ In short, while it has generally enjoyed greater freedom than its print rivals, the online press in Malaysia has not been immune to harassment or censorship and recent events suggest that the government is ramping up censorship online.

As we saw throughout this section, the Malaysian state has used harsh censorship laws to target outlets and individuals that it sees as problematic, generally because of their criticism of the $\mathrm{BN}$ and its allies. To some extent, less-harsh restrictions and censorship of online sources help to explain the much greater neutrality of new media outlets. However, the government has, at times, proved willing to bring tools of censorship to bear against online journalists. Different levels of censorship, therefore, can only explain part of the large difference in bias between the print and online media. Additionally, the Chinese print media is subject to the same censorship mechanisms as the Malay and Anglophone media, yet has proved to be significantly more independent. The next section, therefore, will show that part of this variation is the result of varying ownership of Malaysia's media.

\section{Ownership Structures}

A major mechanism through which the $\mathrm{BN}$ has been able to ensure a progovernment bias in the print media is the ownership structure of the country's leading newspapers, which have long been linked to accounts of cronyism among Malaysia's political and corporate elite (e.g., Gomez 1990; Gomez and Jomo 1999; Abdul Aziz 2005). Ownership structures closely tie several major Malay and Anglophone papers to the ruling coalition. By contrast, Chinese-language papers are almost entirely in the hands of two Chinese tycoons and online media is privately held by a greater variety of individuals and companies. This section delves more deeply into these ties to highlight the difference between the highly biased Malay and Anglophone press and the much more neutral Chinese and online outlets. 
Between 1972 and 2001, the New Straits Times Press was owned by three different holding companies linked to the United Malays National Organization, specifically the Fleet Group, Renong, and then Malaysia Resources Corporation Berhad. In 2001, the corporation's media subsidiaries were divested and subsequently acquired by Media Prima, which today publishes Berita Harian, the New Straits Times, and Harian Metro as well as owns all private free-to-air television networks in the country. The largest shareholder in Media Prima today, at 18.4 percent, is the Malaysia Employees Provident Fund (EPF), ${ }^{33}$ followed by the private firm Gabungan Kesturi with 11.5 percent. The former is a government agency charged with encouraging long-term banking to mitigate for retirement, unemployment, or sickness. While little is known about Gabungan Kesturi, a 2005 report in Business Times claimed that it was owned by Amanah Raya, a trust management company wholly owned by the Malaysian government through the Ministry of Finance. ${ }^{34}$ Thus, while nominally under private ownership, Media Prima is a good example of the complex web of relations between corporate Malaysia, the government, UMNO, and the media. While the NSTP is indirectly linked to the ruling coalition via such ties, UMNO directly owns a controlling interest (approximately 50 percent) in Utusan Melayu Press, which publishes Utusan Malaysia, the daily tabloid Kosmo, and the weekly newspapers Mingguan Malaysia and Utusan Zaman.

In 1977, Huaren Holdings, the investment arm of the Malaysian Chinese Association, bought a controlling interest in The Star. In 2010, the MCA took direct control of the newspaper by buying out Huaren's 42.4 percent share. The MCA argued that the decision was solely motivated by a desire for Huaren to focus its efforts on other investments.

In 2001, Huaren Holdings also acquired over 70 percent of the stock in Nanyang Press, the publishers of the major Chinese-language papers Nanyang Siang Pau and China Press. ${ }^{35}$ However, protests against this acquisition led to a collapse in the market share of Nanyang Siang Pau and forced Huaren to divest the majority of its holdings five years later to Sarawak timber tycoon Tiong Hiew King, who had previously acquired both Sin Chew Jit Poh and Guan Ming Daily. ${ }^{36}$ In 2010, Huaren sold its remaining stake in Media Chinese International, the new holding company for all four Chinese papers. Lau Hui Kiang, another Chinese tycoon, controls Malaysia's other major Chinese newspapers the See Hua Daily and the Oriental Daily (Sun 2009).

Not only do the major online news sources in Malaysia lack direct or indirect ownership ties to the Malaysian state, they are generally founded and funded by individuals and organizations explicitly interested in providing Malaysians with impartial news. Malaysiakini has re- 
ceived funding from the National Endowment for Democracy (NED) and other international donors interested in a free press. The publication is also 70 percent owned by its cofounders and staff. ${ }^{37}$ The newer Free Malaysia Today, originally an opposition coalition blog, is largely funded by anonymous private donors. ${ }^{38}$ In contrast, the ownership of the Malaysian Insider is less clear-cut. It is claimed that the anonymous businessmen who provided the funds to set up and run the news portal had close political ties to Prime Minister Abdullah Badawi. ${ }^{39}$ After Abdullah stepped down in 2009 , however, the news portal took a much more impartial position and was even barred from attending UMNO's General Assembly in 2009 because of its critical coverage of the BN. ${ }^{40}$ In June 2014, the site was bought by The Edge Media Group, which publishes the business weekly The Edge. While the newspaper is widely praised for the quality of its reportage and its editorial independence, critics point to the parent company NexNews's links to Vincent Tan, a controversial corporate ally of former prime minister Mahathir Mohamad. ${ }^{41}$

This section shows that while most major Malay papers and some online outlets maintain ties to the state and the ruling BN coalition, substantial differences in ownership structures seem to explain part of the greater independence of Chinese and online outlets. As we have shown, the BN maintains a much closer relationship with major traditional Malay and Anglophone outlets. UMNO has relatively direct ownership of Utusan Malaysia, Mingguan Malaysia, and Kosmo! (Guan 2010) and is tightly linked to Berita Harian, Harian Metro, and the New Strait Times through Media Prima.

While the MCA retains its direct ownership of the best-selling Anglophone paper, The Star, its relinquishing of two major Chinese papers helps explain the greater independence of the Chinese media. Although the tycoon owners of the major Chinese papers do maintain cozy relationships with key figures in the BN (Straumann 2014), ${ }^{42}$ their substantial fortunes and influence may help ensure that their papers are not mere mouthpieces for $\mathrm{BN}$ politicians and place more emphasis on factors other than politics, such as readership and profits. Finally, the ownership of online publications is generally even further removed from the influence of the ruling coalition.

The argument that ownership explains much of the variation in bias in Malaysia's media is strengthened by the dramatic increase in bias we saw in the New Straits Times. Losing their parliamentary supermajority for the first time in 2008 arguably served as a wake-up call to the $\mathrm{BN}$ and one of their reactions appears to have been to ramp up their influence on the media. Since most of the major papers directly or in- 
directly owned by the BN were already highly biased, it was primarily in the formerly more neutral New Straits Times that this extra influence was most evident.

\section{Conclusion}

This piece has reviewed three independent projects to code bias in Malaysia's media. With surprisingly few discrepancies these studies show that Malaysia's media is generally biased in favor of the ruling $\mathrm{BN}$ coalition, but that online and Chinese-language sources are notably less biased. These results have important implications both for Malaysia's future as well as other hybrid and authoritarian regimes.

The variation in bias across Malaysia's media shows both the effectiveness and the limits of authoritarian attempts to influence the media. The BN has managed to entrench a significant and ongoing bias into many of Malaysia's most important newspapers. Yet the BN still lost its supermajority in 2008 and, despite the further ramping up of its efforts at influencing the media (as was particularly evident in the New Straits Times), it managed to lose the popular vote in 2013. This lack of effectiveness may arise from the fact that a number of outlets, such as the major Chinese papers, still manage to resist BN pressure. Additionally, these long-standing outlets are increasingly being joined by ever more important and remarkably impartial online sources.

As online news sites proliferate, increase in popularity, and become more commercially viable, it is possible that traditional print media may become less overtly biased in order to compete and survive. Nonetheless, any prediction that online news will erode the overall pro-BN bias of the country's media is probably overly optimistic. For decades the Chinese media has provided fairly evenhanded coverage, but this has done little to force other outlets to be more impartial. Additionally, online news sites are still far less established than their traditional competitors, with even the most successful, Malaysiakini, employing a fraction of the staff of its print rivals..$^{43}$ Moreover, for the time being, none are commercially viable without additional sources of income from anonymous benefactors ${ }^{44}$ or foreign grants. Even more worryingly, threatened by their loss of the popular vote in the 2013 elections, the BN seems to have ramped up repression of online sources.

Malaysia represents a hybrid regime that seeks a degree of democratic legitimacy through semicompetitive elections and democratic practices while simultaneously constraining those practices with repressive and coercive powers (Schedler 2006). The country's mediascape 
therefore offers a number of lessons for scholars of hybrid regimes such as Russia and Singapore as well as more coercive regimes such as China: First, control of the media is an important political battleground. Indeed, maintaining control of the media has helped the BN and its predecessors to win every one of Malaysia's elections since independence. Second, ownership (especially indirect) and control of news outlets can prove far more effective and less obviously damaging to legitimacy than draconian censorship. Ownership links have allowed the BN to highly bias Malay and Anglophone outlets in its favor. Three, some level of media dissent is easily tolerated and minority opposition voices may even help legitimacy. For decades, the BN has managed to win elections easily despite a relatively independent Chinese and, to a lesser extent, Anglophone press. Four, online media may eventually prove a game-changer. The BN's share of the popular vote has begun to slip seriously in the last two elections, a phenomenon that is at least correlated with and linked to, if not caused exclusively by, the rise of popular independent online news. If new media does help to unseat the Barisan Nasional in some future election, leaders from both authoritarian and hybrid regimes will certainly take note.

Jason Abbott is the Aung San Suu Kyi Endowed Chair in Asian Democracy and the director of the Center for Asian Democracy at the University of Louisville. Dr. Abbott previously held positions at the University of Surrey, the School of Oriental and African Studies at the University of London, and the Nottingham Trent University. $\mathrm{He}$ is the author/editor of five books and over thirty articles and book chapters on issues of democratization, economic development, political economy, and regional security in Southeast Asia, and Malaysia in particular.

John Wagner Givens is a Center Associate at the Asian Studies Center, University of Pittsburgh. He previously held positions as a Postdoctoral Research Associate at the Center for Asian Democracy, University of Louisville, and as a Clarendon Scholar at the University of Oxford. Dr. Givens's research focuses on politics and law in China and research methods in Asian comparative politics.

\section{Notes}

1. Prior to 1973 the ruling coalition was known as The Alliance and consisted of UMNO, the Malaysian Chinese Association, and the Malaysian Indian Congress.

2. "Malaysia's Press Freedom Ranking Drops to All-Time Low of 147," Malaysian Insider, February 12, 2014. www.themalaysianinsider.com/malaysia /article/malaysias-press-freedom-ranking-drops-to-historic-low-of-147 (accessed March 26, 2014). 
3. One of the difficulties in measuring an audience on the Internet is determining the difference between page views and unique visits. The former represents the number of times a page is tracked by analytics software and is not necessarily indicative of audience share since any time an individual user clicks on a page during a visit it records it as a page view. Unique visits, on the other hand, simply track the entrance of a user to a web page. It represents therefore the first hit. The problem with unique visits is that it does not count what the user subsequently does and, since today a user can visit from multiple devices, one user can also make multiple unique visits.

4. Figures courtesy of Malaysiakini. http://advertisemalaysiakini .blogspot.com (accessed March 26, 2014). Figures from the Malaysian Digital Media Association for October 2013 gave Malaysiakini 906,000 unique visitors and the Malaysian Insider 663,000.

5. Ibid.

6. Interview with Prem Chandran, Petaling Jaya, July 18, 2013.

7. Interview with Jahabar Sadiq, CEO and editor of the Malaysian Insider, July $22,2013$.

8. Ibid.

9. FMT Borneo Plus was officially launched on January 14, 2014.

10. Email correspondence with Tessa Houghton, University of Nottingham Malaysia Campus, March 12, 2014. Houghton was one of the leading collaborators in the Watching the Watchdog project.

11. For example, if Malaysiakini had three progovernment articles and two anti-opposition articles on one day that is coded at 1 ; if those numbers were reversed it would be -1 .

12. The Comparative National Elections Project is run out of the Ohio State University. The project involves a multiyear, multicountry study of how citizens in democracies worldwide receive information about issues, candidates, and politics during election campaigns. For more information, see Richard Gunther, "Comparative National Elections Project," Mershon Center for International Studies. http://mershoncenter.osu.edu/expertise/institutions/cnep.htm.

13. Email from Steven Gan, editor of Malaysiakini, February 14, 2015.

14. Kit Siang was convicted for receiving information concerning the purchase of Swedish warships by the Malaysian navy (Sani 2005).

15. Barbara Crosette, "Malaysian Secret Laws Used as New Curb," New York Times, November 4, 1985. www.nytimes.com/1985/11/04/world /malaysian-secrets-law-is-used-as-a-news-curb.html.

16. Ibid.

17. Such sensitive issues include Malay special privileges, the status of Malay as both the official and national language, the status of Islam as the official religion, the citizenship rights of non-Malays, and the sovereignty of the Malay rulers.

18. In 2013 Tian Chua, vice president of the opposition National Justice Party (PKR), and Hishamuddin Rais were charged with making seditious speeches at an opposition event in Selangor, while in February and May 2014 Karpal Singh and Teresa Kok, members of parliament for the opposition Democratic Action Party, were convicted and charged, respectively, for seditious comments. 
19. On July 18, 2013, bloggers Alvin Tan and Vivian Lee were charged and imprisoned for promoting enmity between different groups of religion or race for posting a Ramadan greeting with the two of them eating pork. See K. Pragleth, "Alvin, Vivian Charged; Bail Rejected," Free Malaysia Today, July 18, 2013. www.freemalaysiatoday.com/category/nation/2013/07/18/bak-kut-teh-couplecharged-bail-rejected.

20. On February 11, 2015, cartoonist Zulkiflee Anwar Ulhaque (Zunar) was arrested for tweeting critically about the decision by the Malaysian Federal Court to find opposition leader Anwar Ibrahim guilty of sodomy.

21. PAS was forced to restrict the publication of its newspaper Harakah from biweekly to bimonthly (see Abbott 2001).

22. "Paper Shut Down for Breaching Guidelines," Star (Malaysia), April 18, 2008. http://thestar.com.my/news/story.asp?file=/2008/4/18/nation/20987996 (accessed November 25, 2009).

23. Bob Dietz, "No Joke: Malaysian Cartoonist Stands Up to Government," Committee to Protect Journalists, February 27, 2012. https://www.cpj.org/blog /2012/02/malaysian-cartoonist-zunar-stands-up-to-government.php (accessed March 26, 2014).

24. Prem, interview.

25. Sadiq, interview.

26. Lau, Interview.

27. "Dr. M: Rethink Absolute Freedom on Net," Malaysian Insider, June 3, 2012. www.themalaysianinsider.com/malaysia/article/dr-m-rethink-absolutefreedom-on-net/\#sthash.MD8z2Fan.dpbs.

28. "Hishamuddin Rais: We're Excellent at 'Bodekcology,"' Malaysian Digest, January 13, 2010. www.malaysiandigest.com/features/42-personality/1631hishamuddin-rais-were-excellent.html (accessed February 18, 2010).

29. Peter Walker, "Malaysia's Mission Unbloggable," Guardian, December 5, 2006. www.theguardian.com/news/blog/2006/dec/05/malaysiablogb (accessed June 19, 2015).

30. Rowan Walker, “Malaysia Blogger's Arrest Creates Dangerous Precedent," Guardian, September 12, 2008. www.guardian.co.uk/news/blog /2008/sep/12/malaysia.internet (accessed December 11, 2009).

31. Austin Ramzy, "Editors and Executives of News Website Malaysian Insider Are Arrested," New York Times, March 31, 2015. www.nytimes.com /2015/04/01/world/asia/malaysian-insider-arrests.html?_r=0 (accessed June 19, 2015).

32. "Malaysia Extends Sedition Law to Allow Online Censorship," Committee to Protect Journalists, April 13, 2015. https://cpj.org/2015/04/malaysia-extends-sedition-law-to-allow-online-cens.php (accessed June 19, 2015).

33. www.mediaprima.com.my/wp-content/uploads/2014/07/an/MediaPrimaAR2011.pdf.

34. "Gabungan Kesturi, EPF Raise Stakes in Media Prima," Business Times, January $8,2005$.

35. Siow Chen Ming, “A Cash Cow for Huaren," The Edge, March 23, 2009. www.theedgemalaysia.com/features/3961-a-cash-cow-for-huaren.html (accessed March 14, 2014). 
36. Ng Tien Eng, "Daily vs. Daily: Challenging the Big Boys," Aliran Monthly, July 23, 2003. http://aliran.com/archives/monthly/2003/71.html (accessed March 10, 2014).

37. "Malaysiakini Admits to Receiving Foreign Funds," The Star Online, September 22, 2012. www.thestar.com.my/story/?file=\%2F2012\%2F9 \%2F22\%2Fnation\%2F12067491 (accessed June 19, 2015).

38. FMT Borneo Plus was officially launched on January 14, 2014.

39. Interview with Gan in ibid.; interview with $\mathrm{K}$. Kabilan, editor of Free Malaysia Today, July 19, 2013; interview with Leslie Lau, executive editor of the Malay Mail, July 2013.

40. See Deborah Loh, "Internet Media Barred from UMNO," The Nut Graph, March 29, 2009. www.thenutgraph.com/internet-media-barred-from-umno.

41. Malaysiakini, "Newcomer NexNews Buys Sun and Edge for RM54 Mil," January 22, 2002. www.malaysiakini.com/news/6357.

42. Tiong was particularly close to Abdul Taib Muhamad, who from 1981 to 2014 was chief minister of Sarawak and leader of the largest political party in the state, Parti Pesaka Bumiputera Bersatu (PBB). The PBB is currently the largest political party in Sarawak and since the 2013 federal election is the secondlargest constituent party in the Barisan Nasional after UMNO.

43. Malaysiakini employs approximately sixty staff, the Insider about thirty (including ten reporters), and Free Malaysia Today a similar figure to the Insider following its expansion to East Malaysia. The Star, by contrast, has a 1,600strong workforce.

44. Interview with Jacqueline Surin, editor of The Nut Graph, July 30, 2013.

\section{References}

Abbott, Jason.2001. "Democracy@internet.asia. The Challenges to the Emancipatory Potential of the Net: Lessons from China and Malaysia." Third World Quarterly 22, 1: 99-114.

- -.2011 . "Electoral Authoritarianism and the Print Media in Malaysia: Measuring Political Bias." Asian Affairs: An American Review 38, 1: 1-38. Abbott, Jason P., and Sophie Gregorios-Pippas. 2010. "Islamization in Malaysia: Processes and Dynamics." Contemporary Politics 16, 1: 135-151. doi:10.1080/13569771003783851.

Abbott, Jason, Andrew MacDonald, and John Wagner Givens. 2013. "New Social Media and (Electronic) Democratization in East and Southeast Asia: China and Malaysia Compared." Taiwan Journal of Democracy 9, 1: 105-137.

Abdul Aziz, Tunku, S. Hadi Abdullah (editor), and K. S. Sieh (editor). 2005. Fighting Corruption: My Mission, Konrad Adenauer Foundation.

Barr, Michael D., and Anantha Raman Govindasamy. 2010. "The Islamisation of Malaysia: Religious Nationalism in the Service of Ethnonationalism." Australian Journal of International Affairs 64, 3: 293-311.

Brown, Graham. 2005. "The Rough and Rosy Road: Sites of Contestation in Malaysia's Shackled Media Industry.” Pacific Affairs 78: 39-56. 
Case, William. 1997. "Malaysia: Still the Semi-Democratic Paradigm.” Asian Studies Review 21, 2/3: 79.

Chin, James. 2013. "Editorial: Chinese Tsunami or Urban Revolt? It Is Both Actually." The Round Table 102, 6: 499-501. doi:10.1080 /00358533.2013.857170.

- -.2015 . "Malaysia: Pseudo-Democracy and the Making of a Malay-Islamic State." In Routledge Handbook of Southeast Asian Democratization, ed. W. Case, 399-409. London: Routledge.

CNN.com. 2001. "Malaysian Police Arrest Opposition Leaders." April 11. http://edition.cnn.com/2001/WORLD/asiapcf/southeast/04/11/malaysia .arrest/index.html (accessed July 21, 2014).

Collier, David, and Steven Levitsky. 1997. "Democracy with Adjectives: Conceptual Innovation in Comparative Research." World Politics 49: 430-451.

Eng, Ng Tien. 2003. "Daily vs. Daily: Challenging the Big Boys." Aliran Monthly, July 23. http://aliran.com/archives/monthly/2003/71.html (accessed July 17, 2014).

"Gabungan Kesturi, EPF Raise Stakes in Media Prima." 2005. Business Times, January 8.

George, Cherian. 2007. "Media in Malaysia: Zone of Contention." Democratization 14, 5: 893-910.

Givens, John Wagner, Jason P. Abbott, and Jason Gainous. 2015. "Malaysian Elections, Urbanization, and the Resilience of Electoral Authoritarianism." Working paper on file with authors.

Gomez, Edmund Terrence. "Politics in Business: UMNO's Corporate Investments." Forum, 1990.

Gomez, Edmund Terrence, and K. S. Jomo, 1999, Malaysia's Political Economy: Politics, Patronage and Profits, Cambridge: Cambridge University Press.

Gong, Rachel. 2011. "Internet Politics and State Media Control: Candidate Weblogs in Malaysia." Sociological Perspectives 54, 3: 307-328.

Government of Malaysia. 2008. Federal Constitution. Kuala Lumpur: International Law Book Services.

Grant, Jeremy. 2013. "Malaysia's 'Chinese Tsunami' Puts Najib in a Bind.” Financial Times, May 7, sec. Global Insight. www.ft.com/intl/cms /s/0/460f0c42-b711-11e2-841e-00144feabdc0.html\#axzz3AUMqW6uy.

Guan, Yeoh Seng. 2010. Media, Culture and Society in Malaysia. London: Routledge.

Hassid, Jonathan, and Rachel E. Stern. 2012. "Amplifying Silence: Uncertainty and Control Parables in Contemporary China." Comparative Political Studies 45 .

Houghton, Tessa, and Zaharom Nain. 2013. "Watching the Watchdog: Monitoring Media Coverage of the 13th General Elections." Center for Independent Journalism. www.nottingham.edu.my/Modern-Languages/Centreforthe StudyofCommunicationsandCulture/CSCCResearch/Watching-the-Watchdog.aspx (accessed July 17, 2014). 
Jesudason, James V. 1995. "Statist Democracy and the Limits to Civil Society in Malaysia." Journal of Commonwealth and Comparative Politics 33, 3: 334-356.

Lepawsky, J. 2005. "Digital Aspirations: Malaysia and the Multimedia Super Corridor." American Geographical Society's Focus on Geography 48, 3: $10-18$.

Liow, Joseph Chinyong. 2012. "Malaysia's March 2008 General Election: Understanding the New Media Factor." Pacific Review 25, 3: 293-315.

Lumsden, Linda. 2013. "How Independent? An Analysis of GE13 Coverage by Malaysia's Online News Portal Coverage.” Jurnal Kimmunikasi [Malaysian Journal of Communication] 29, 2: 1-30.

Malaysia Audit Bureau Circulations. Various Years. Circulation Reports. www.abcm.org.my.

Malaysian Communications and Multimedia Commission. 2013. Communications and Multimedia Pocket Book of Statistics Q2.

Ottaway, Marina. 2003. Democracy Challenged: The Rise of Semi-Authoritarianism. Washington, DC: Carnegie Endowment for International Peace.

Pepinsky, Thomas B. 2009. "The 2008 Malaysian Elections: An End to Ethnic Politics?" Journal of East Asian Studies 9: 87-120.

- - - 2014. "Post-Election Report 2013 Malaysian Election: Part II-The Monkey Cage." http://themonkeycage.org/2013/05/13/post-election-report2013-malaysian-election-part-ii (accessed November 7, 2014).

Politweet.org. 2013. "The Rural-Urban Divide in Malaysia's General Election." https://politweet.wordpress.com/2013/05/21/the-rural-urban-divide-inmalaysias-general-election (accessed February 16, 2014).

Rodan, Garry. 2004. Transparency and Authoritarian Rule in Southeast Asia: Singapore and Malaysia. London: Routledge.

Sani, Mohd Azizuddin Mohd. 2005. "Media Freedom in Malaysia." Journal of Contemporary Asia 35: 349.

Sankaran, Calvin. 2014. "Mathematical Proof of Chinese Tsunami." Free Malaysia Today. www.freemalaysiatoday.com/category/opinion/2013/07/31 /13th-ge-mathematical-proof-of-chinese-tsunami (accessed August 15, 2014).

Schedler, Andreas. 2006. Electoral Authoritarianism: The Dynamics of Unfree Competition. London: Lynne Rienner.

Shadmehr, Mehdi, and Dan Bernhardt. 2013. "State Censorship." American Economic Journal. http://moya.bus.miami.edu/ mshadmehr/Censorship.pdf.

Siow, Chen Ming. 2009. "A Cash Cow for Huaren." The Edge, March 23. www.theedgemalaysia.com/features/3961-a-cash-cow-for-huaren.html (accessed July 17, 2014).

The Star (Malaysia). 2008. "Paper Shut Down for Breaching Guidelines." April 18. http://thestar.com.my/news/story.asp?file=/2008/4/18/nation/20987996 (accessed July 17, 2014).

Straumann, Lukas. 2014. Money Logging: On the Trail of the Asian Timber Mafia, Basel: Bergli Books.

Sun, Wanning. 2009. Media and the Chinese Diaspora: Community, Communications and Commerce. London: Routledge. 
Surin, Jacqueline Ann. 2010. "Occupying the Internet: Responding to the Shifting Power Balance." Round Table 99, 407: 195-209.

Tapsell, Ross. 2013. "The Media Freedom Movement in Malaysia and the Electoral Authoritarian Regime." Journal of Contemporary Asia 43, 4: 613-635.

Thean, Janice Melissa. 2013. "Newspaper Readership Drops Sharply on GE Backlash." The Edge, October 8. www.theedgemalaysia.com/media-aadvertising/257885-newspaper-readership-drops-sharply-on-gebacklash.html (accessed July 17, 2014).

Ting, Alan. 2010. "Huaren Holdings Sells Stakes in Media Chinese." My Sinchew, September 24. www.mysinchew.com/node/45437.

Weiss, Meredith L. 2013. "Parsing the Power of 'New Media' in Malaysia." Journal of Contemporary Asia 43, 4: 591-612.

Welsh, Bridget. 2013. "Malaysia's Elections: A Step Backward." Journal of Democracy 24, 4: 136-150.

Zakaria, Fareed. 2003. The Future of Freedom: Illiberal Democracy at Home and Abroad. New York: Norton and Company.

Zakaria, Haji Ahmad. 1989. "Malaysia: Quasi Democracy in a Divided Society." In Democracy in Developing Countries: Asia, ed. Larry Jay Diamond, Juan Jose Linz, and Seymour Martin Lipset, 347-382. Boulder: Lynne Rienner. 